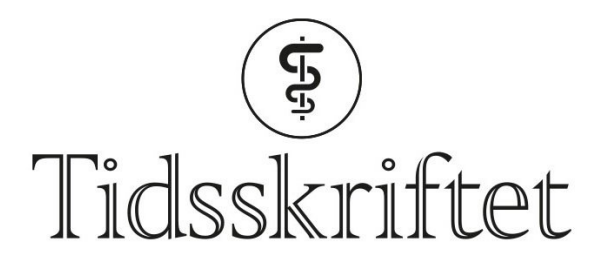

DEN NORSKE LEGEFORENING

\title{
Korona, karantene og krise
}

SPRÅKSPALTEN

\section{ERLEND HEM}

E-post: erlend.hem@medisin.uio.no

Erlend Hem er professor dr.med., fagsjef og redaktør for Tidsskriftets språkspalte.

Koronaviruspandemien har også noen språklige konsekvenser.

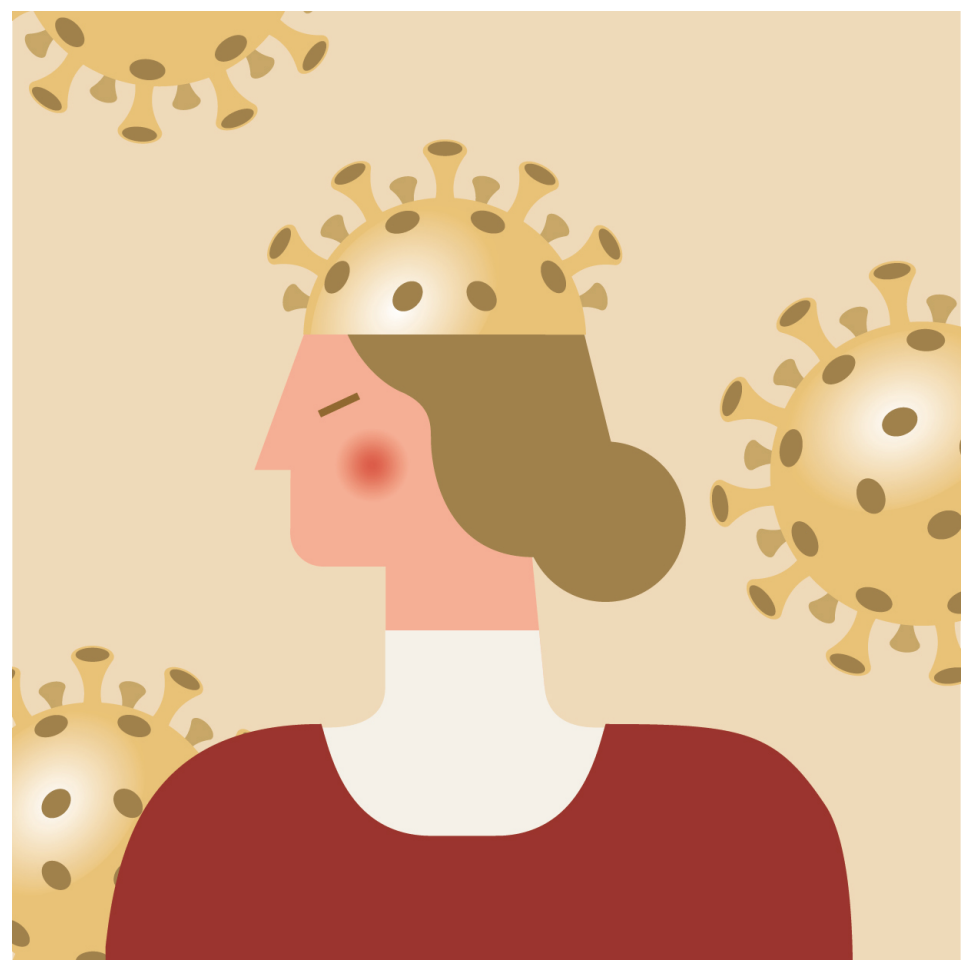

Illustrasjon: sorbetto/iStock, tilpasset av Tidsskriftet.

I desember 2019 ble det påvist en ny type koronavirus i byen Wuhan i Kina. I februar 2020 fikk viruset og sykdommen som viruset forårsaker, offisielle navn. Verdens helseorganisasjon (WHO) bestemte at sykdommen skal kalles covid-19 (1). På engelsk skrives det med store bokstaver, men på norsk pleier vi å skrive med små, som sars, mers og aids.

Komiteen som har ansvar for virustaksonomi, bestemte at viruset skal skrives sars-CoV-2 (1). Det betyr at vi kan ha setninger som denne: «Han ble smittet av sars-CoV-2 og utviklet etter hvert covid-19."

\section{Korona}

Både forkjølelse, sars, mers og covid-19 har opphav i den store koronavirusfamilien (2). Ordet korona kommer fra latin corona, som betyr 'krans' eller 'krone'. Viruset har fått navn 
etter hvordan det ser ut i et elektronmikroskop: rundt med en membran med små, utstikkende pigger som kan minne om det ytterste laget av solas atmosfære, koronaen (3). Språkrådet anbefaler å skrive korona med $k$, og sammensetningen koronavirus er et vanlig fellesnavn som skrives med liten forbokstav (4). Noe av poenget med å skrive koronavirus med $k$ er at vi har ordet korona fra før i norsk. Medisinere vil kjenne det igjen fra hjertets koronararterier, som vi også kaller kransarterier.

\section{Karantene}

I Store norske leksikon kan vi lese om ordet karantene at det i medisinsk sammenheng benyttes «om tiltak som har til hensikt å begrense kontakten mellom personer som kan tenkes å være rammet av en smittsom sykdom, og andre mennesker» (5).

Ordet kommer fra det italienske quarantina (6). Vi gjenfinner det i mange europeiske språk: karantän (svensk), karantcene (dansk), quarantine (engelsk), quarantaine (fransk), Quarantäne (tysk), cuarentena (spansk) osv. På italiensk betyr quaranta 'førti', og avsperringen i de første karantenebestemmelsene varte i 40 dager (6).

I forbindelse med koronaviruspandemien definerte Folkehelseinstituttet skillet mellom sosial distansering, karantene og isolering (5). Sosial distansering handler ifølge Store norske leksikon om at «folk flest skal holde større avstand til hverandre enn vanlig, for eksempel i butikker, på arbeidsplasser og i det offentlige rommet ellers». Karantene betyr at "personer som ikke er syke, men som har vært i mulig smitteoverførende situasjoner, skal holde seg borte fra kontakt med andre», mens isolering «benyttes når man er smitteførende og det må iverksettes spesielle tiltak for å hindre smitte til andre» (5).

\section{Krise}

Da WHO 11.3.2020 definerte koronaepidemien som en pandemi, forsto verden at den sto overfor en krise. Ordet krisis (av gresk: 'avgjørelse, dom') har røtter tilbake til oldtidas medisin. En medisinsk krise dreide seg om et avgjørende vendepunkt da sykdommen enten førte til døden eller klinget av. Kriser inntraff på «kritiske dager», et visst antall dager siden sykdomsdebuten (7). I dag brukes ikke krise på denne måten. Nå betyr ordet 'svært vanskelig, farlig situasjon' (8).

I allmennspråket er krisebegrepet blitt utvannet. Nå kan man snakke om krise ved helt alminnelige og hverdagslige hendelser som enten er pinlige, vanskelige eller bare ergerlige: «Det er litt krise.» Koronapandemien er noe annet. Det er helt krise.

\section{LITTERATUR:}

1. Verdens helseorganisasjon. Naming the coronavirus disease (COVID-19) and the virus that causes it. https://www.who.int/emergencies/diseases/novel-coronavirus-2019/technical-guidance/naming-the-co ronavirus-disease-(covid-2019)-and-the-virus-that-causes-it Lest 17.3.2020.

2. Hem E. MERS eller mers? Tidsskr Nor Legeforen 2016; 136:1911. [PubMed][CrossRef]

3. Klein J, Dalgard O, Jensen HLB. Koronavirus. I: Store medisinske leksikon.

https://sml.snl.no/koronavirus Lest 17.3.2020.

4. Språkrådet. Koronavirus. https://www.sprakradet.no/Vi-og-vart/hva-skjer/Aktuelt-ord/koronavirus/ Lest 17.3.2020.

5. Braut GS. Karantene - smitte. I: Store norske leksikon. https://snl.no/karantene_-_smitte Lest 17.3.2020.

6. Hem E. Karantene - om mer enn sykdom. Tidsskr Nor Legeforen 2013; 133: 1851. [PubMed][CrossRef]

7. Hem E. Den medisinske krise. Tidsskr Nor Legeforen 2018; 138. doi: 10.4045/tidsskr.17.0401.

[PubMed][CrossRef] 
8. Krise. I: Det Norske Akademis ordbok. https://www.naob.no/ordbok/krise_1 Lest 17.3.2020.

Publisert: 25. mars 2020. Tidsskr Nor Legeforen. DOI: 10.4045/tidsskr.20.0235

(C) Tidsskrift for Den norske legeforening 2020. Lastet ned fra tidsskriftet.no 